\section{Arabic Language as Representation of Muslim Identity in}

\section{Indonesia}

\author{
Yuangga Kurnia Yahya ${ }^{1}$, Umi Mahmudah ${ }^{2}$, Siti Nikmatul Rochma ${ }^{3}$ \\ 1,2,3 Universitas Darussalam Gontor, Indonesia \\ Email: yuangga4@unida.gontor.ac.id,umimahmudah@unida.gontor.ac.id, \\ nikmatul.rochma@unida.gontor.ac.id
}

\begin{abstract}
:
This study is a qualitative research by collecting data from multiple sites that discuss the importance of learning the Arabic language for the people of Indonesia. Top 5 sites with those keywords are Rumaysho.com., BelajarIslam.com, Islampos.com, Kompasiana.com., and kiblat.net. From those five sites will be analyzed with the Yasir Suleiman's language and religious identity perspective which shows that language has a function as an instrument of communication and also, a symbol of identity. This study found that stereotyping against the Arabic language makes it even more exclusive and closed to non-Muslims in Indonesia. Learning the Arabic language itself is not limited to the religious orientation, but making it as a function of language itself, as a medium of communication. Arabic language has been 'sacred' with its strategic position in political, economical, ideological, and academic field.
\end{abstract}

Keywords:

Arabic language; language of Islam; religious identity

\section{Introduction}

Learning a foreign language in Indonesia has increased year by year. This can be seen in used language everyday data released by the BPS (Badan Pusat Statistik) in which as much as $0.35 \%$ of Indonesia's population using foreign languages (Badan Pusat Statistik, 2010). The learned foreign language are also diverse. According to data from the English First (EF) in anakui.com sites, there are five foreign language studied by Indonesian society. Those are English, Korean, Japanese, Chinese, and Arabic. However, some learning institutions add French as a foreign language that is interested in Indonesia society.

There are some reasons for Indonesian people to learn foreign languages. English language clearly tops the list because it is the international language in various domains, such as academic, political, economic, business, etc. in the context of Indonesian development and utilizing science and technology (Agustin, 2011). Korean and Japanese both are became favorite language after the outbreak of 'Korea fever' (Ardia, 2014) and Japanese culture in the form of anime, manga, and so on to Indonesia (Novianti, 2007). Mandarin studied in facing the free competition in this globalization era (Sutami, 2016).

The last one is Arabic. A language that is familiar with this widely studied Islamic religion in Indonesia with a variety reasons. But, the majority of the reason in studying Arabic in Indonesia is dominated by religious reasons as to understand the Qur'an, Hadith, and other Islamic Sharia sourced from books in Arabic or in Wahab's language (Wahab, 2007) for a religious orientation purposes. 


\section{Lakhomi Journal: Scientific Journal of Culture \\ ISSN: 2774-311X (Online), 2774-4728 (Print)}

Vol. 2, No. 2, June 2021, Page: 82-88

Email: lakhomijournal@gmail.com

Religious orientation in learning Arabic in Indonesia makes Arabic became the sacred language and more exclusive. Exclusivity of Arabic can be seen from the number of non-Muslim communities in Indonesia studied Arabic. A research written by Wahyuni (2011) (I. W. Wahyuni, Ahmad, \& Mulyanti, 2011) shows that as much as 33.59\% non-Muslim students at SDN 016 Kab. Kampar, show a negative attitude in attending Arabic-Malay classes. Another research by Wahyuni (2017) (I. Wahyuni, 2017) also indicates that learning Arabic in FTIK IIAN Kendari is inseparable from the religious context. It is inversely proportional to the Arabic for Non-Native Speakers program organized by Qatar University for two semesters for example. In the academic year 2019-2020, this program was attended by students from various countries such as India, Japan, Korea, Mongolia, Russia, Norway, Kazakhstan, Turkey, Indonesia, several countries in Europe and Africa, as well as several countries in Asia Southeast.

The whole participants are divided into three groups. The first one is The Advance level (mutaqaddim), the second is the Intermediate level (mutawassith) and the last one is elementary level (mubtadi'). In mutaqaddim class, participants consisted of $64 \%$ Muslims and 36\% of nonMuslims. In mutawassith class, Muslim participants as much as $81 \%$ of the total. The remaining $19 \%$ is non-muslim participants. Lastly, in the mubtadi' classroom, non-Muslim participants reached $37 \%$ of the total. Totally, from all level programs, non-Muslim participants reached $27 \%$ of the total participants. These numbers show non-Muslim interest in studying Arabic culture and language are quite large.

In that program, participants from non-Arab countries and with non-Muslims from the non-Muslims have capabilities that are not much different from the Muslim students in Arabic language skills. Even some of them achieved the best speakers in the Arabic language conversation among non-native speakers. This indicates that the non-Muslims was a very keen interest in the mastery of Arabic. Another side effect from this exclusivity is the Arabic became sacred and holy for most among Muslims. This is shown from the case of "Arabic words on slippers ", " Arabic word on Agnes Monica's clothes", until shirt allegedly loaded with Christianization because the Lord's Prayer in Arabic written on it.

These phenomenons confirm that the Arabic language according to the majority Muslim community in Indonesia is sacred and exclusive language. The language that has a function as a medium of communication and messages-deliverer become something sacred and can not be misused. This is the underlying research that will analyze the phenomenon of Arabic language as representation of Muslim Identity in Indonesia.

\section{Research Methods}

Suleiman explained that languages, including Arabic has two functions. First, the language as instruments of communication and second, as a symbol and identity of a group. The second function is also called the primordial nature of language (primordiality of language) was born because language is a product of culture and society (Suleiman, 2003). Two paradigms that happens are nationalism, ethnicity, and identity are constructed through language or language that is constructed into a symbol of certain identity, ethnicity, and nationalism (Rajagopalan, 2016). However, in many cases, the primordial nature of the language often becomes more dominant and separator between the groups or other speaking-communities (Suleiman, 2003). This phenomenon makes the language as a communication tool instead turns into a communication breaker with other people. 
Language is a man-made technology to communicate with others (Dor, 2015). To be a communication tool, the language must be intersubjectively with the interaction between speaker and hearer (cooperation), the collective mind (collective thought), and the same production of culture (cultural production)(Dor, 2015). When language become more closed and be exclusive, its functions as an instrument of communication are limited, and even injured.

Sacred is one aspect of religion that sanctifies a certain object or entity. The opposite of profane is 'ordinary thing`. An object or entity does not become sacred because of its nature, but rather the belief given by people to the entity. Therefore, in the English language, it expressed by 'sacred', not 'sacring' or 'sacral'. This is due to the construction of holiness is something 'given'[12] [13],

In this article, researcher took data from the top five sites using the keyword 'the importance of learning Arabic' (pentingnya belajar bahasa Arab). The five sites are Rumaysho.com., BelajarIslam.com, Islampos.com, Kompasiana.com., and kiblat.net. Reasons to learn Arabic in those sites become the object to be analyzed regarding the relationship between learning Arabic and Muslim communities stigma in Indonesia.

\section{Results and Discussion}

\subsection{Exclusivism Arabic in Indonesia}

By using the keyword "the importance of learning Arabic", researcher found many sites that give reasons to learn Arabic. For example, in Rumaysho.com, 7 reasons to learn Arabic were written. In an article entitled ' 7 alasan harus belajar bahasa Arab' written by Muhammad Abduh Tuasikal, M.Sc. on January 12, 2016 told the number of reasons. These reasons include 1) because Arabic is the language of al-Qur'an; 2) learning Arabic is an Islamic syi'ar; 3) benefit to understand Shariah and Islamic scholarship, and 4) It is a glorious language which is revelation of God delivered in that language.

In BelajarIslam.com sites, reasons to learn Arabic are divided into 7 reasons. The seven reasons are; 1) Arabic as syi'ar Islam; 2) Arabic is a language rite of Muslims in prayer and worship; 3) Proficiency in Arabic has a strong influence on the way of thinking (logic), morality, and religion; 4) It makes people can be similar to the companions of the Prophet SAW and has noble character like them; 5) Arabic is the language of religion; 6) To understand the Qur'an and Sunnah; and 7) to make someone better (faqih) in speech. This article titled ' 7 alasan kenapa kita harus belajar bahasa Arab' which refers to Iqtidha 'Ash-shirath Al-Mustaqim book written by Ibn Taymiyyah.

The site Islampos.com, also cited seven reasons for a Muslim in Indonesia to learn Arabic. The reasons are to understand the words of Allah without relying on translation; to understand the hadith (prophetic tradition) of the Prophet Muhammad; to increase khusyu' in prayer and worship; to understanding the books of the Islamic scholars; it is one of the five most common languages in the world; to increase the employment opportunities; and also, learning a new language implicates to improve brain performance and memory power. All those reasons are summarized in an article titled 'Inilah 7 alasan mengapa anda harus belajar bahasa Arab' written by Adam.

In Kompasiana.com site, in an article entitled 'Bahasa Arab sebagai bahasa Internasional', written by Ardin Jae mentioned a few reasons to learn Arabic. First, because it is the language of al-Qur'an. Second, it makes understanding of Islamic teaching from the classics books more 
easier. Third, the sentences and words are not too much because usually only consists of three letters. Fourth, because it is one of the important international language in intercultural communication in the realm of economics, politics, and so forth.

Recently, the site kiblat.net find out an article entitled '7 alasan logis kenapa anda musti belajar bahasa Arab’ written by M. Rudy from Ilmfeed. In that article written on July 14, 2016 the reasons which require an Indonesia Muslim to learn Arabic language. These reasons are; 1) Through the Arabic language, people can understand the verses of Allah without translation; 2) Through the Arabic language, people can easily understand the hadith of the Prophet Muhammad; 3) It is possible to increase khusyu' in prayer and worship; 4) To understand the science of religion from its original sources; 5) Arabic is one international languages; 6) to expand employment opportunities, and 7) to strengthen the brain's memory.

From the various reasons above, only two reasons are not related to religion, both are to expand employment opportunities and to strengthen the memory and logic. Moreover, the purpose of the study of Arabic is a "sacred duty" that can not be done by people of other faiths. Starting from the facility to understand the Qur'an, hadith, Islamic classic books as a reference source of Islam, the language of the rites of worship and prayer, follow the teachings of the Prophet and His companions to improve khusyu' in prayer and worship. In other words, Arabic is instrument of communication in Islam(Pane, 2018).

The learning purposes create a phenomenon called sacralization of Arabic language. For example, in 2016, Agnes Monica was condemned by several people for using clothes that written "الل دـ تحدة" 'union` on it(Ihsanudin, 2019). She was considered insulting Muslims with that appearance. A similar thing happened with the Lord's Prayer in Matthew written by Arabic on the shirt in various clothing outlets. The word is "misleading Calligraphy" 'Kaligrafi yang menyesatkan '(Widjaja, 2008) and " Christian Calligraphy Appears Again, People Must Beware" 'Lagi-lagi Kaligrafi Kristen Beredar, Umat Mesti Hati-Hati' (Hidayat, 2016). The latest case is the phenomenon of slippers that reads "يد "kanan`and" شمال "kiri considered an act of humiliation of al-Qur'an. The majority of those who blaspheme reasoned that what was done is a form of humiliation for Muslims and Arabic, the sacred language which used in their holy scriptures.

This sacralization does not happen without reason. Because of the orientation of learning Arabic dominated by religious orientation, then Muslim community's perception of the Arabic language become something religious as well. Sacralization of things in religion, according to Eliade, means to make something ordinary (profane) has a holy and sacred values(Agus, 2007; Eliade, 1959). Sanctity does not lie in the object, but the perception and constructs built by the system of rituals and beliefs of the religion that makes it sacred.

Holy book al-Qur'an is a sacred appropriate because it was believed to be the revelation of Allah. Arabic became the medium of al-Qur'an also be sacred, especially for non-Arabic speakers Muslims. In fact, ordinary letters as shown on the Agnes Monica's shirt and sandals above, are considered sacred even though it had a profane meaning. Neither the Christian Prayers written on T-shirts, even though it is a non-Islamic texts, remain trapped in the context of Islam because it written in Arabic('Aid, 1989; Suleiman, 2003).

That phenomenon makes Arabic language movement more limited. It was limited to only as the language of Islamic rituals and has sacred nature. That means that Arabic language learners in Indonesia are dominated by Muslims with religious reasons. This was alluded to by Suleiman 
(Suleiman, 2003) that Arabic has lost its primary function as an instrument of communication and means of relieving gap (bridges the gap). Arabic is more synonymous with its function as a religious identity rather than as an instrument of communication. In Edwards's statements, function as the language-prestige is more dominant than the function as the languagefunction(Edwards, 1996). It played the role of homogeneus community binder and as a marker of religious identity(Jaspal \& Coyle, 2010).

\subsection{Arabic Is (not only) Language of Islam}

Arabic language and al-Qur'an indeed can not be separated. With al-Qur'an, Arabic language, especially fuscha style, inherited and maintained authenticity remains to this day(Fachrudin, 2017). The diversity of dialects of Arabic, even in fuscha style itself, raising fears of a loss of fuscha diversity. This is why the books of al-Qur'an in one mushaf. No doubt, learning al-Qur'an will not be complete without preceded with the ability to master the Arabic language. Various linguistics sciences such as syntax, morphology, language styles, and semantics are also developed from al-Qur'an(Al-Faruqi \& Al-Faruqi, 2003).

Although both are inseparable, actually Arabic language and language of al-Quran has quite a lot of differences. One of them is the language of al-Qur'an is a high-level language in Arabic literature. This is because it revealed to the Prophet Muhammad during the golden ages of Arabic literatures. Therefore, when studying the Arabic language in order to understand the contents of the content of al-Qur'an, then it is at the highest level after mastering syntax, morphology, semantics even Arabic styles(Al-Faruqi \& Al-Faruqi, 2003).

However, the Arabic language is not just a language rite (liturgical language). Arabic is also an instrument of communication, even more than that, the vehicle of culture and civilization (vehicle for a renowned culture and civilization)(Bakalla, 1984) or cultural agents(Fachrudin, 2017). Furthermore, it has a similar position with the Greek and Latin in the transmission of knowledge in the world.

Various works of science transmissed and transformed from Greece to Europe after being translated, developed, even some emerging science in the Arab world. Baghdad, Andalusia, and Sicilia are the names of cities that became the center of the translation and the development of science (Misbahuddin, 2015). In other words, the golden age of Islam in the 8th century up to 11th century, Arabic transformed into the language of international science(Bakalla, 1984) or also known as the 'Language of Science and Thought'(Khalifah, 2003).

In addition to culture and science, in the Middle Ages, Arabic was the language of diplomacy and international administration. It took over from Greek, Persian, Latin, Ancient Egypt, and Siriac. Thus, Arabic is the official language of international in North Africa, Egypt, Jordan, Syria, Iraq, and Lebanon(Nasution, 1974). At least 25 countries make Arabic as the official language of their country and 6 countries put it as their second official language. Arabic is also the language with the most speakers in the African continent, specifically located in North Africa(Bakalla, 1984; Bale, 2010; Yahya, 2019). According to Babbel Magazine, in 2019, the Arabic language is spoken by 313 million people around the world and makes it the most international language with speakers of the 5th after Mandarin, Spanish, English, and India.

The data above shows that the adoption of Arabic as one of the official languages of the $\mathrm{UN}$ is not a coincidence. Arabic is the international language in many countries. Learning the Arabic language is an important matter in the interests of economic, political, diplomatic, and knowledge in this modern era. 
A previous study mentioned that the Christian community in the West Asia and North Africa also do their worship in Arabic. In fact, they also translated the Bible into Arabic and used in worship(Yahya, 2018). Bale(Bale, 2010) mentioned that the majority of Arabic speakers in the United States is derived from non-Muslims. It is become an irony when Indonesian Muslims claim that Arabic is only limited for Muslims. Therefore, it is correct statement from Wahab(Wahab, 2007) that Arabic language learning orientation in Indonesia is divided into four purposes. Those are religious, academic, professional, and ideological-economic purposes. Those purposes are suit various positions in Arabic as mentioned above.

Arabic language sacralization that led to language exclusivism for Indonesian Muslims make it lose its strategic position on various aspects. The mindset is in line with the mindset of European linguist, André Martinet when he first looked at the language of the East. He thought that Persian, Sanskrit, Pali, and Arabic are sacred languages and only used in religious rites and ceremonies, and also controlled by religious leaders only('Ayāsyi, 1990) or become liturgical language(Jaspal \& Coyle, 2010). Whereas in fact, the nature of language is become the instrument of communication and message-delivering can not be separated from any language, even in primitive form of language (Khalifah, 2003). Arabic language de-sacralization as an instrument of communication will restore its position back into the international language which is not limited to any particular religion.

\section{Conclusion}

Arabic is one of the foreign languages that interested for Indonesian people and also one of international languages. However, the awareness to learn this language is still relatively low because the sacralization from the users. As a result, the position of Arabic in the eyes of nonMuslims Indonesia only as the language of Islam and did not have any advantage to learn. Instead of studying Arabic, they prefer to learn Korean, Japanese, Mandarin, and French. It was born from the exclusive perception (and even convictions) Arabic by Muslims in Indonesia. Various reasons for the study of Arabic-Islamic dominated by religious reasons. As the result, all the writings in Arabic are considered sacred and had a close relationship with al-Qur'an. No doubt, various insults society born of ignorance that Arabic in addition to functioning as a symbol of religious identity, have a more fundamental functions, as an instrument of communication and message-delivering. Restoring Arabic to its original position or desacralization, as a communication instrument did not reduce its 'sacrality'. Instead of history proved it as one language into the transmission of knowledge, culture, and civilization of mankind. A position that is much larger and holistic than if only the prerogative of the Muslims alone.

\section{References}

'Ayāsyi, M. (1990). Qadhāyā Lisāniyyah wa Chadloriyyah. Damascus: Dar Tlass.

'Aid, M. (1989). Qadhāyā Mu'āshirah fi ad-Dirāsāt al-Lughawiyyah wa'l Adabiyyah. Cairo: 'Alam al-Kutub.

Agus, B. (2007). Agama Dalam Kehidupan Manusia: Pengantar Antropologi Agama. Jakarta: PT Rajagrafindo Persada.

Agustin, Y. (2011). Kedudukan Bahasa Inggris Sebagai Bahasa Pengantar Dalam Dunia Pendidikan. Deiksis, 03(04), 354-364.

Al-Faruqi, I. R., \& Al-Faruqi, L. L. (2003). Atlas Budaya Islam, Terj.Ilyas Hasan (IV). Bandung: Penerbit Mizan.

Ardia, V. (2014). Drama korea dan Budaya Popular. Jurnal Komunikasi, 2(3), 12-18. 
Badan Pusat Statistik. (2010). Kewarganegaraan, Suku bangsa, Agama dan Bahasa Sehari-hari Penduduk Indonesia: Hasil Sensus Penduduk 2010. Jakarta: Badan Pusat Statistik.

Bakalla, M. H. (1984). Arabic Culture: Through its Language and Literature. London: Keegan Paul International, Ltd.

Bale, J. (2010). Arabic as a heritage language in the United States. International Multilingual Research Journal, 4(2), 125-151. https://doi.org/10.1080/19313152.2010.499041

Dor, D. (2015). The Instruction of Imagination: Language as a social Communication Technology. https://doi.org/10.1017/CBO9781107415324.004

Edwards, J. (1996). Language, Prestige, and Stigma. In Contact Linguistics. New York: de Gruyter.

Eliade, M. (1959). The sacred and the profane: The nature of religion, Trans. Willard R Trask. In Harcourt, Brace \& World, Inc. New York: A Harvest Book.

Fachrudin, A. A. (2017). Pengantar Sejarah dan Madzhab Linguistik Arab. Malang: CV. Lisan Arabi.

Hidayat, S. (2016). Lagi-lagi Kaligrafi Kristen Beredar, Ummat Islam Mesti Hati-hati. Retrieved March 17, 2020, from Kaligrafi-Islam.blogspot.com website: https://perma.cc/Z9C6W9KK

Ihsanudin, I. (2019). Polemik "Tulisan Arab" Pada Busana Agnes Monica (Analisis Teori Interaksionisme Simbolik). Palita: Journal of Social-Religion Research, 4(1), 47-60. https://doi.org/10.24256/pal.v4i1.526

Jaspal, R., \& Coyle, A. (2010). "Arabic is the language of the Muslims-that's how it was supposed to be": Exploring language and religious identity through reflective accounts from young British-born South Asians. Mental Health, Religion and Culture, 13(1), 17-36. https://doi.org/10.1080/13674670903127205

Khalīfah, 'Abd al-Karīm. (2003). Al-Lughah al-'Arabiyyah 'ala Madāriji al-Qarni al-Wāchid wa'l 'Isyrīn. Beirut: Dār al-Gharb al-Islamy.

Misbahuddin, M. (2015). SICILIA: Jembatan Transmisi Keilmuan Islam ke Eropa. Khatulistiwa, 5(1), 32-42. https://doi.org/10.24260/khatulistiwa.v5i1.263

Nasution, H. (1974). Islam Ditinjau dari berbagai Aspeknya. Jakarta: Penerbit Bulan Bintang.

Novianti, N. (2007). Dampak Drama, Anime, dan Musik Jepang terhadap Minat Belajar Bahasa Jepang. Lingua Cultura, 1(2), 151-156. https://doi.org/10.21512/lc.v1i2.321

Pane, A. (2018). Urgensi Bahasa Arab; Bahasa Arab Sebagai Alat Komunikasi Agama Islam. Komunikologi: Jurnal Pengembangan Ilmu Komunikasi Dan Sosial, 2(1), 77-88.

Rajagopalan, K. (2016). Language and identity: national, ethnic, religious (Book Review). WORD, 62(4), 276-280. https://doi.org/10.1080/00437956.2016.1248656

Suleiman, Y. (2003). The Arabic Language and National Identity: A Study in Ideology. In Edinburgh University Press. https://doi.org/10.1525/jlin.2005.15.2.281

Sutami, H. (2016). Fungsi dan Kedudukan Bahasa Mandarin di Indonesia. Paradigma, Jurnal Kajian Budaya, 2(2), 212-238. https://doi.org/10.17510/paradigma.v2i2.28

Wahab, M. A. (2007). Tantangan dan Prospek Pendidikan Bahasa Arab di Indonesia. Afaq Arabiyyah, 2(1), 1-18.

Wahyuni, I. (2017). Bahasa Arab Dalam Konteks Simbol Agama (Analisis Terhadap Tujuan Pembelajaran pada Perguruan Tinggi Islam). Zawiyah: Jurnal Pemikiran Islam, 3(2), 78-92.

Wahyuni, I. W., Ahmad, M., \& Mulyanti, S. (2011). Sikap Siswa Non Muslim dalam Mengikuti Pelajaran Arab Melayu. Jurnal Al-Hikmah, 8(1), 88-95.

Widjaja, I. (2008). Kaligrafi yang Menyesatkan, Waspadalah! Retrieved March 17, 2020, from Indrawibowo.com website: https://perma.cc/98JV-EASY

Yahya, Y. K. (2018). Lexemes Mean God In Al-Qur' An And Arabic Gospel: Semantic Analysis. Lisanudhad, 05(02), 105-126.

Yahya, Y. K. (2019). Pengaruh Penyebaran Islam di Timur Tengah dan Afrika Utara: Studi Geobudaya dan Geopolitik. Al-Tsaqafa: Jurnal Peradaban Islam, 16(1), 44-62. 